\title{
A lake classification concept for a more accurate global estimate of the dissolved inorganic carbon export from terrestrial ecosystems to inland waters
}

\author{
Fabian Engel ${ }^{1}$ (D) Kaitlin J. Farrell 2,3 - lan M. McCullough ${ }^{4} \cdot$ Facundo Scordo $^{5} \cdot$ Blaize A. Denfeld $^{6} \cdot$ Hilary A. Dugan $^{7}$. \\ Elvira de Eyto ${ }^{8} \cdot$ Paul C. Hanson ${ }^{7} \cdot$ Ryan P. McClure ${ }^{3} \cdot$ Peeter Nõges $^{9} \cdot$ Tiina Nõges $^{9} \cdot$ Elizabeth Ryder $^{10}$. \\ Kathleen C. Weathers ${ }^{11} \cdot$ Gesa A. Weyhenmeyer ${ }^{1}$
}

Received: 13 December 2017 / Revised: 12 February 2018 / Accepted: 23 February 2018 / Published online: 26 March 2018

(C) The Author(s) 2018. This article is an open access publication

\begin{abstract}
The magnitude of lateral dissolved inorganic carbon (DIC) export from terrestrial ecosystems to inland waters strongly influences the estimate of the global terrestrial carbon dioxide $\left(\mathrm{CO}_{2}\right)$ sink. At present, no reliable number of this export is available, and the few studies estimating the lateral DIC export assume that all lakes on Earth function similarly. However, lakes can function along a continuum from passive carbon transporters (passive open channels) to highly active carbon transformers with efficient in-lake $\mathrm{CO}_{2}$ production and loss. We developed and applied a conceptual model to demonstrate how the assumed function of lakes in carbon cycling can affect calculations of the global lateral DIC export from terrestrial ecosystems to inland waters. Using global data on in-lake $\mathrm{CO}_{2}$ production by mineralization as well as $\mathrm{CO}_{2}$ loss by emission, primary production, and carbonate precipitation in lakes, we estimated that the global lateral DIC export can lie within the range of $0.70_{-0.31}^{+0.27}$ to $1.52_{-0.90}^{+1.09}{\mathrm{Pg} \mathrm{C} \mathrm{yr}^{-1}}^{-1}$ depending on the assumed function of lakes. Thus, the considered lake function has a large effect on the calculated lateral DIC export from terrestrial ecosystems to inland waters. We conclude that more robust estimates of $\mathrm{CO}_{2}$ sinks and sources will require the classification of lakes into their predominant function. This functional lake classification concept becomes particularly important for the estimation of future $\mathrm{CO}_{2}$ sinks and sources, since in-lake carbon transformation is predicted to be altered with climate change.
\end{abstract}

Keywords Global carbon cycle $\cdot$ Lake functioning $\cdot$ Hydrologic $\mathrm{CO}_{2}$ transport $\cdot$ Lake carbon cycling $\cdot$ Earth system models $\cdot$ Lake primary production

Communicated by: Sven Thatje

Fabian Engel

Fabian.Engel@ebc.uu.se

1 Department of Ecology and Genetics/Limnology, Uppsala University, Norbyvägen 18D, 75236 Uppsala, Sweden

2 Odum School of Ecology, University of Georgia, Athens, GA 30602, USA

3 Department of Biological Sciences, Virginia Tech, Derring Hall, Blacksburg, VA 24061, USA

4 Bren School of Environmental Science and Management, University of California, Santa Barbara, CA 93106, USA

5 Instituto Argentino de Oceanografía (UNS-CONICET), Florida 8000 (Camino La Carrindanga km 7,5), B8000BFW Bahía

Blanca, Buenos Aires, Argentina
Department of Ecology and Environmental Sciences, Umeå University, Linnaeus väg 6, 90187 Umeå, Sweden

7 Center for Limnology, University of Wisconsin-Madison, $680 \mathrm{~N}$. Park St., Madison, WI, USA

8 Marine Institute, Furnace, Newport, Co. Mayo, Ireland

9 Centre for Limnology, Estonian University of Life Sciences, Kreutzwaldi 1, 51014 Tartu, Estonia

10 Centre for Freshwater and Environmental Studies, Dundalk Institute of Technology, Dundalk, Co Louth, Ireland

11 Cary Institute of Ecosystem Studies, Millbrook, NY 12545, USA 


\section{Integrating inland waters into Earth system models}

Earth system models (ESMs) simulate the interactions between global climate and biogeochemical cycles based on the physical, chemical, and biological properties of the three main components of the Earth system: land, atmosphere, and ocean. Connecting atmospheric transport, ocean circulation, and terrestrial biosphere models (TBMs; land) allows simulation of carbon stores and fluxes at the global scale (Falkowski et al. 2000; IPCC 2013). TBMs simulate biogeochemical and physical processes of terrestrial ecosystems, including up to 25 key processes (Fisher et al. 2014). While global terrestrial gross primary production $\left(\mathrm{GPP}_{\text {land }}\right)$ can be measured using satellite remote sensing data, autotrophic and heterotrophic respiration of land ecosystems $\left(R_{a}\right.$ and $R_{h}$, respectively) need to be simulated in current TBMs. In TBMs, the biomass production on land is quantified as net primary production $\left(\mathrm{NPP}_{\text {land }} ; \mathrm{NPP}_{\text {land }}=\mathrm{GPP}_{\text {land }}-\mathrm{R}_{\mathrm{a}}\right)$, while the amount of carbon stored in or released from terrestrial ecosystems, terrestrial net ecosystem production ( $\left.\mathrm{NEP}_{\text {land }}\right)$, is obtained by subtracting the total terrestrial ecosystem respiration $\left(\mathrm{R}_{\mathrm{a}}+\right.$ $\mathrm{R}_{\mathrm{h}}$ ) from $\mathrm{GPP}_{\text {land }}$ (Fisher et al. 2014). Inland waters connect the Earth system components land and ocean (Cole et al. 2007; Drake et al. 2017; Tranvik et al. 2009). However, current ESMs do not simulate carbon fluxes in inland waters (Bauer et al. 2013). Instead, inland waters were for a long time regarded as "passive pipes" between land and ocean. Recently, aquatic carbon fluxes were integrated into TBMs on a regional scale (Langerwisch et al. 2016).

In recent years, the view of inland waters being passive carbon transporters between land and ocean has changed. Instead, lakes have been identified as important regulators of carbon processing along the land to ocean aquatic continuum (LOAC) (Battin et al. 2009; Biddanda 2017; Cole et al. 2007; Tranvik et al. 2009). The functioning of lakes in carbon transport and transformation controls both lateral (i.e., hydrologic transport) and vertical (i.e., emission and burial) carbon fluxes along the LOAC and thus influences the global carbon balance (Battin et al. 2009; Biddanda 2017; Cole et al. 2007; Tranvik et al. 2009). These findings have important implications for the calculation of the $\mathrm{NEP}_{\text {land }}$ in TBMs. When the proportion of $\mathrm{R}_{\mathrm{h}}$ from terrestrial biomass that leaves terrestrial ecosystems through lateral hydrologic export to streams and lakes (Oquist et al. 2014) is not accounted for when simulating $\mathrm{R}_{\mathrm{h}}, \mathrm{NEP}_{\text {land }}$ is overestimated. The recognition of the importance of lateral aquatic carbon transport for continental carbon budgets has led to the realization that terrestrial ecosystems are less efficient in sequestering carbon than previously assumed (Butman et al. 2016; Ciais et al. 2008). A recent study showed that the $\mathrm{NEP}_{\text {land }}$ of the conterminous USA might have been overestimated by more than $25 \%$, as lateral aquatic carbon fluxes were not accounted for in present TBMs (Butman et al. 2016). Thus, realistic estimates of the terrestrial carbon sink/source require accurate quantification of the lateral carbon export from terrestrial ecosystems to inland waters. These estimates are currently not available and are unrealistic to measure over large geographic regions. Thus, the inclusion of lateral inland water carbon fluxes into global ESMs remains difficult, but essential if we seek to reconcile global carbon budgets (Battin et al. 2009; Butman et al. 2016; Weyhenmeyer et al. 2015).

\section{Lake functioning along the aquatic continuum}

Rivers, floodplains, and lakes control carbon transport as well as transformation along the LOAC (Cole et al. 2007; Raymond et al. 2013; Tranvik et al. 2009). The integration of lakes into global carbon dioxide $\left(\mathrm{CO}_{2}\right)$ budgets is difficult, since lakes function differently depending on their characteristics and location (Tranvik et al. 2009). Nutrient conditions, hydrology, catchment characteristics, lake morphology, and regional climate are important factors determining the functioning of lakes in the global carbon cycle (Lewis Jr. 2011; Tranvik et al. 2009; Weyhenmeyer et al. 2015). The role of lakes in dissolved inorganic carbon (DIC) transport and transformation (Fig. 1) depends on the characteristics of each lake. In-lake $\mathrm{CO}_{2}$ consumption and production might, for example, be the most important drivers of lake carbon dynamics in warm eutrophic lakes (Almeida et al. 2016), while lateral $\mathrm{CO}_{2}$ transport can be highly significant in boreal lakes (Weyhenmeyer et al. 2015). Although decomposition rates of organic carbon are higher in lakes with short water residence times (Catalán et al. 2016), short water residence times generally result in lower in-lake $\mathrm{CO}_{2}$ production and consumption, if the majority of carbon is transported downstream before being processed (Tranvik et al. 2009).

At present, different assumptions regarding the functioning of lakes in the global carbon cycle are found in the literature. Many global carbon estimates, including those currently used for policy decisions (IPCC 2013), assume that in lakes, $\mathrm{CO}_{2}$ is efficiently produced by mineralization of terrestrial dissolved organic carbon (DOC) (Aufdenkampe et al. 2011; Battin et al. 2009; Cole et al. 2007; IPCC 2013; Raymond et al. 2013; Tranvik et al. 2009). However, assuming that all lakes function similarly can be problematic since the transformation of DOC to $\mathrm{CO}_{2}$ in many lakes is less efficient than previously thought (McDonald et al. 2013; Stets et al. 2009; Weyhenmeyer et al. 2015). In numerous lakes, a large proportion of the emitted $\mathrm{CO}_{2}$ originates from terrestrial ecosystem respiration $\left(\mathrm{R}_{\mathrm{h}}\right)$ and has been transported to inland waters via discharge (Weyhenmeyer et al. 2015). Assuming this $\mathrm{CO}_{2}$ to be produced by in-lake DOC mineralization results in an overestimation of $\mathrm{NEP}_{\text {land }}$ in TBMs and ESMs. Thus, assumptions about lake 


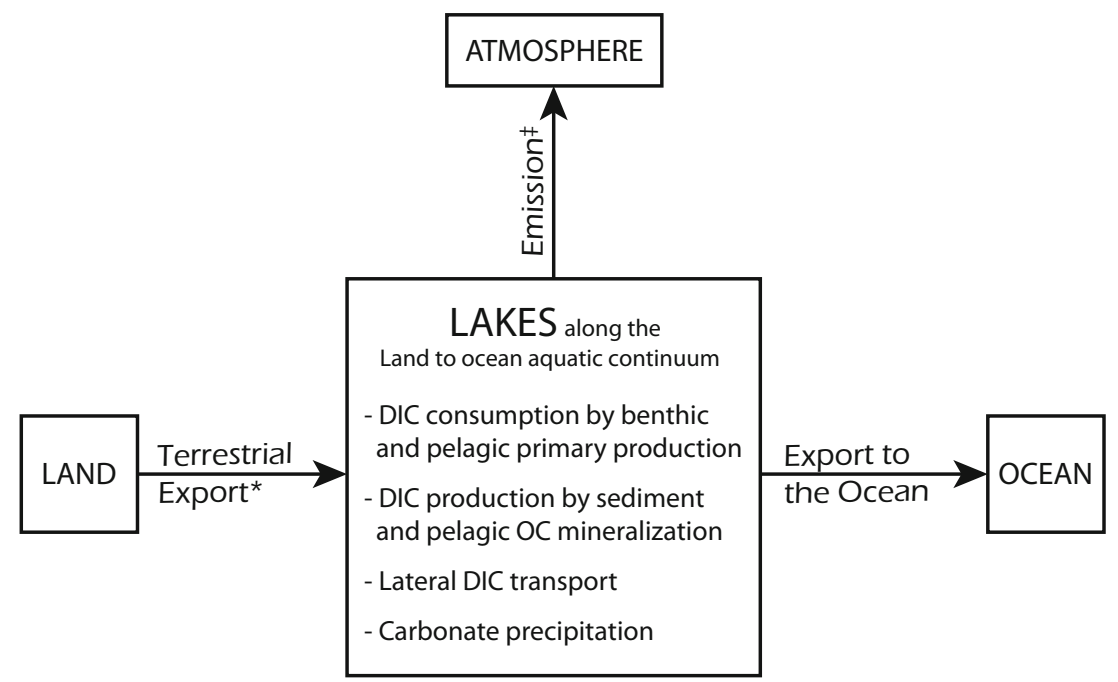

Fig. 1 Schematic representation of the role of lakes in dissolved inorganic carbon (DIC) cycling along the land to ocean aquatic continuum (LOAC) showing the main global DIC fluxes and in-lake transformation processes. Organic carbon sedimentation and burial is not included in this conceptualization, since we restricted our analysis to DIC fluxes

functioning have a large impact on the calculated lateral DIC export from terrestrial ecosystems to inland waters.

The aim of this study was to develop a conceptual model to quantify variations in the estimate of the global lateral DIC export from terrestrial ecosystems to inland waters, depending on the assumed predominant function of lakes.

\section{A lake classification concept and effects on the global terrestrial DIC export}

To integrate lakes into ESMs, we classified lakes into three functional categories: (1) lakes as active carbon transformers, (2) lakes as intermediate active carbon transformers, and (3) lakes as passive open channels, where classes 1 and 3 represent the ends of a continuum of possible lake functioning depending on lake characteristics (Fig. 2).

To demonstrate the effect of different assumptions about lake functioning on calculated estimates of DIC export from terrestrial ecosystems to inland waters (streams, rivers, lakes, and reservoirs), we established the following mass-balance equation by accounting for all main DIC fluxes along the LOAC (Fig. 1):

$$
\begin{aligned}
\mathrm{DIC}_{\text {export }}= & \mathrm{DIC}_{\text {ocean }}+\mathrm{CO}_{2} \text { emission } \\
& +\mathrm{CCP}_{\text {lake }}+\mathrm{GPP}_{\text {lake }}-\mathrm{MIN}_{\text {lake }}+\mathrm{CO}_{2 \_} \text {emission }_{\text {lotic }} \\
& +\mathrm{GPP}_{\text {lotic }}+\mathrm{CCP}_{\text {lotic }}-\mathrm{MIN}_{\text {lotic }}
\end{aligned}
$$

where $\mathrm{DIC}_{\text {export }}$ is the DIC exported from terrestrial ecosystems to inland waters, $\mathrm{DIC}_{\text {ocean }}$ is the DIC entering the oceans via along the LOAC. *Includes surface and groundwater transport from land to lakes. ${ }^{\star}$ In lakes with high DIC consumption, uptake of atmospheric $\mathrm{CO}_{2}$ can partly exceed total emissions resulting in temporarily negative net emissions

lateral surface and groundwater transport, $\mathrm{CO}_{2}$ emission lake $_{\text {is }}$ the net $\mathrm{CO}_{2}$ emission from lakes and reservoirs (hereafter lake), $\mathrm{CO}_{2}$ emission ${ }_{\text {lotic }}$ is the net $\mathrm{CO}_{2}$ emission from streams and rivers (lotic systems), GPP lake is the $\mathrm{CO}_{2}$ consumption by lake primary production, $\mathrm{GPP}_{\text {lotic }}$ is the $\mathrm{CO}_{2}$ consumption by primary production in streams and rivers, $\mathrm{CCP}_{\text {lake }}$ is the in-lake calcium carbonate precipitation, $\mathrm{CCP}_{\text {lotic }}$ is the calcium carbonate precipitation in streams and rivers, $\mathrm{MIN}_{\text {lake }}$ is the amount of $\mathrm{CO}_{2}$ produced by lake mineralization, and $\mathrm{MIN}_{\text {lotic }}$ is the amount of $\mathrm{CO}_{2}$ produced by stream and river mineralization. Organic carbon sedimentation and burial is not included in our conceptual model, since we restricted the analysis to DIC fluxes along the LOAC. Our model (Fig. 2) is meant to provide a conceptual framework that can be applied at different spatial scales with any of the most comprehensive available estimates describing the fluxes stated in Eq. 1.

In lakes that predominantly function as active carbon transformers (e.g., warm eutrophic lake ecosystems (Almeida et al. 2016)), GPP ${ }_{\text {lake }}$ is substantial for the lake carbon budget. The terrestrial DIC export for landscapes in which lakes predominantly function as active carbon transformers can be estimated using Eq. 1.

When assuming lakes to function predominantly as intermediate active carbon transformers, $\mathrm{CO}_{2}$ emissions from lakes would mainly be sustained by in-lake DOC mineralization, and $\mathrm{GPP}_{\text {lake }}$ as well as $\mathrm{CCP}_{\text {lake }}$ would be close to zero. In that case, DIC $_{\text {export }}$ can be estimated as:

$$
\begin{aligned}
\mathrm{DIC}_{\text {export }}= & \mathrm{DIC}_{\text {ocean }}+\mathrm{CO}_{2} \text { emission } \\
\text { lotic } & +\mathrm{GPP}_{\text {lotic }} \\
& +\mathrm{CCP}_{\text {lotic }}-\mathrm{MIN}_{\text {lotic }}
\end{aligned}
$$


Fig. 2 Conceptual figure showing two ends of a continuum of lake functions in the cycling of dissolved inorganic carbon (DIC). The figure also demonstrates how lake functioning may shift depending on runoff, water retention time, nutrient loading, and algal blooms. Organic carbon sedimentation and burial are not included in this conceptualization, since we restricted our analysis to DIC fluxes in lakes

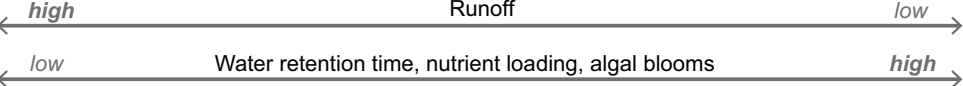

\section{Lakes as passive open channels}

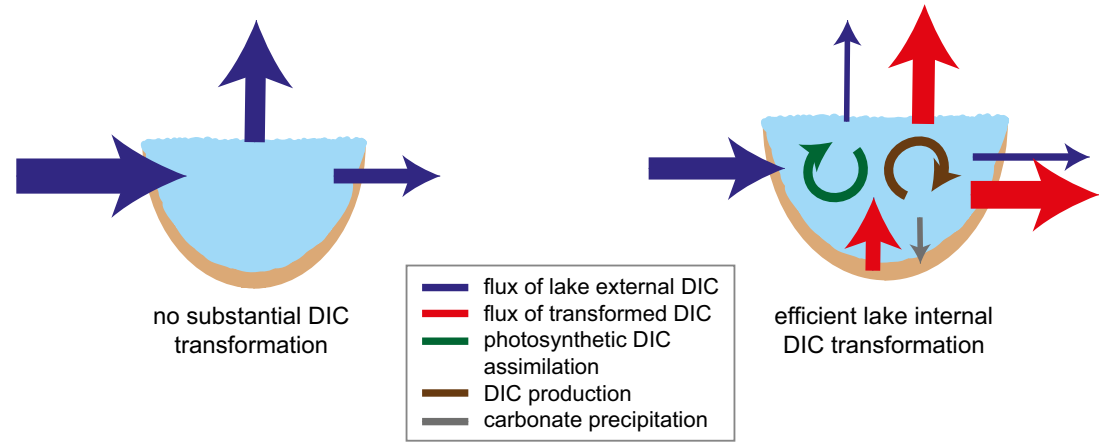

Lakes as active transformers
This intermediate lake function reflects that some lakes, often referred to as heterotrophic lakes, have high bacterial and photochemical $\mathrm{CO}_{2}$ production, and DOC-derived $\mathrm{CO}_{2}$ is the main source of lake $\mathrm{CO}_{2}$ emissions. These lakes have little phytoplankton and zooplankton production, which is typical for some boreal lakes (Jonsson et al. 2001) and probably even for nutrient-poor and deep lakes. Assuming $\mathrm{CO}_{2}$ _emission ${ }_{\text {lake }}$ and $\mathrm{MIN}_{\text {lake }}$ approach zero in Eq. 2 does not indicate that these lakes have no in-lake carbon transformation, but that the $\mathrm{CO}_{2}$ production in these lakes is mainly sustained by mineralization of allochthonous organic carbon. Thus, for this lake type, $\mathrm{CO}_{2}$ emission ${ }_{\text {lake }}$ cannot be included as flux term when calculating the DIC export from terrestrial ecosystems to inland waters. This lake function reflects the way global lakes are currently accounted for in ESMs, where it is assumed that $\mathrm{CO}_{2}$ in inland waters originates mainly from in-lake mineralization of allochthonous organic carbon (Aufdenkampe et al. 2011; Battin et al. 2009; Cole et al. 2007; IPCC 2013; Raymond et al. 2013; Tranvik et al. 2009).

When instead assuming that lakes predominantly function as passive open channels (e.g., small boreal and temperate lakes (Jonsson et al. 2003; Stets et al. 2009)), GPP lake, $\mathrm{CCP}_{\text {lake, and }}$ $\mathrm{MIN}_{\text {lake }}$ are minor, and $\mathrm{CO}_{2}$ emissions are mainly sustained by hydrologic DIC inflow to lakes that is derived from terrestrial inorganic carbon export. In this case, we assumed $\mathrm{GPP}_{\text {lake, }}$, $\mathrm{CCP}_{\text {lake, }}$, and $\mathrm{MIN}_{\text {lake }}$ to approach zero in Eq. 1. Thus, with lakes as passive open channels, the $\mathrm{DIC}_{\text {export }}$ can be estimated as:

$$
\begin{gathered}
\mathrm{DIC}_{\text {export }}=\mathrm{DIC}_{\text {ocean }}+\mathrm{CO}_{2} \text {-emission } \\
\text { lake } \\
+\mathrm{GPP}_{\text {lotic }}+\mathrm{CCP}_{\text {lotic }}-\mathrm{MIN}_{\text {lotic }}
\end{gathered}
$$

\section{Sensitivity of the global terrestrial DIC export to lake functioning}

To demonstrate the sensitivity of the global $\mathrm{DIC}_{\text {export }}$ to the assumed functioning of global lakes using Eqs. 1, 2, and 3, we collected published data on global $\mathrm{DIC}_{\mathrm{ocean}}, \mathrm{CO}_{2}$ emission $_{\text {lake, }}$, $\mathrm{CO}_{2}$ emission ${ }_{\text {lotic }}, \mathrm{GPP}_{\text {lake }}, \mathrm{MIN}_{\text {lake }}$, and $\mathrm{MIN}_{\text {lotic }}$ from the literature (Table 1). For our calculations, we chose the most recent estimate of each respective flux, since these were the most accurate available flux estimates on the global scale. While the esti-

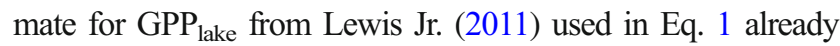
entails a scaling of lake GPP based on the latitudinal distribution of lakes and prevailing nutrient conditions, Raymond et al. (2013) simulated $\mathrm{CO}_{2}$ emission ${ }_{\text {lake }}$ from non-tropical lakes using DOC and lake area and used a median value for tropical lakes in their estimate. Thus, the Raymond et al. (2013) model does not account for $\mathrm{CO}_{2}$ emissions derived from lateral DIC inputs to lakes; hence, lakes that function as passive open channels are excluded. Consequently, scaling global $\mathrm{CO}_{2}$ emission ${ }_{\text {lake }}$ and $\mathrm{MIN}_{\text {lake }}$ according to the assumed predominant lake functions (Eqs. 1, 2, and 3) is reasonable.

Our sensitivity analysis illustrates the likely range of the calculated DIC export from terrestrial ecosystems to inland waters under the assumption of different lake functions. When assuming that all lakes on Earth function as active carbon transformers, $\mathrm{DIC}_{\text {export }}$ according to Eq. 1 equaled

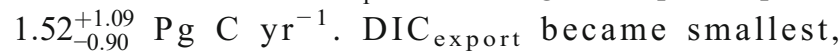
i.e., $0.70_{-0.31}^{+0.27} \mathrm{Pg} \mathrm{C} \mathrm{yr}^{-1}$, when we considered lakes as intermediate active carbon transformers (Eq. 2). When we considered lakes as passive open channels (Eq. 3), the $\mathrm{DIC}_{\text {export }}$ turned to $1.02_{-0.57}^{+0.79} \mathrm{Pg} \mathrm{C} \mathrm{yr}^{-1}$. Thus, we found that calculations of $\mathrm{DIC}_{\text {export }}$ can vary between $0.70_{-0.31}^{+0.27}$ and $1.52_{-0.90}^{+1.09} \mathrm{Pg} \mathrm{C}$ $\mathrm{yr}^{-1}$, depending on the assumed predominant function of lakes (Fig. 3). These numbers for the lateral DIC export are about 25 and $50 \%$ of the total carbon export from terrestrial ecosystems to inland waters estimated by previous studies (Aufdenkampe et al. 2011; Battin et al. 2009; Tranvik et al. 2009). We suggest that the variability in calculated lateral DIC fluxes from terrestrial ecosystems to inland waters has a strong influence on estimates of the terrestrial $\mathrm{CO}_{2}$ sink and might explain a share of the residual terrestrial $\mathrm{CO}_{2}$ sink of approximately $2 \mathrm{Pg} \mathrm{C}$ 
Table 1 Overview of global estimates for dissolved inorganic carbon (DIC) fluxes in inland waters. Values used for the calculation of the DIC export from terrestrial ecosystems to inland waters in our study, i.e., the most recent estimates for the respective flux, are in bold. The upper and lower limits indicate the range of the estimates reported in the respective studies

\begin{tabular}{|c|c|c|c|}
\hline Flux & Abbreviation & Flux estimate $\left[\mathrm{Pg} \mathrm{C} \mathrm{yr}^{-1}\right]$ & Reference \\
\hline DIC export to the oceans & $\mathrm{DIC}_{\text {ocean }}$ & $0.45_{-0.11}^{+0.10}$ & (Cole et al. 2007) \\
\hline $\mathrm{CO}_{2}$ emissions from streams and rivers & $\mathrm{CO}_{2}$ emission ${ }_{\text {lotic }}$ & $\begin{array}{l}\mathbf{0 . 6 5}_{-\mathbf{0 . 2 0}}^{+\mathbf{0 . 1 7}} \\
1.8_{-0.25}^{+0.25} \\
0.56\end{array}$ & $\begin{array}{l}\text { (Lauerwald et al. 2015) } \\
\text { (Raymond et al. 2013) } \\
\text { (Aufdenkampe et al. 2011) }\end{array}$ \\
\hline $\mathrm{CO}_{2}$ emissions from lakes and reservoirs & $\mathrm{CO}_{2}{ }_{2}$ emission ${ }_{\text {lake }}$ & $\begin{array}{l}\mathbf{0 . 3 2} 2_{-\mathbf{0 . 2 6}}^{+0.52} \\
0.64\end{array}$ & $\begin{array}{l}\text { (Raymond et al. 2013) } \\
\text { (Aufdenkampe et al. 2011) }\end{array}$ \\
\hline $\mathrm{CO}_{2}$ consumption by lake gross primary production & $\mathrm{GPP}_{\text {lake }}$ & $\begin{array}{l}\mathbf{1 . 3 _ { - 0 . 2 5 } ^ { + 0 . 2 1 }} \\
0.65\end{array}$ & $\begin{array}{l}\text { (Lewis Jr. 2011) } \\
\text { (Pace and Prairie 2005) }\end{array}$ \\
\hline Lake calcium carbonate precipitation & $\mathrm{CCP}_{\text {lake }}$ & 0.03 & (Meybeck 1993) \\
\hline $\mathrm{CO}_{2}$ production by in-lake mineralization & $\mathrm{MIN}_{\text {lake }}$ & $0.83_{-0.08}^{+0.09}$ & (Pace and Prairie 2005) \\
\hline $\mathrm{CO}_{2}$ production by mineralization in rivers & $\mathrm{MIN}_{\text {lotic }}$ & 0.40 & (Caraco and Cole 1999) \\
\hline
\end{tabular}

$\mathrm{yr}^{-1}$ (Houghton 2003; Nakayama 2017; Schimel 1995). It should be noted that $\mathrm{DIC}_{\text {export }}$ comprises DIC originating from rock weathering as well as soil-derived $\mathrm{CO}_{2}$. Only about $70 \%$ of $\mathrm{DIC}_{\text {export }}$ might be soil derived (i.e., of atmospheric origin), while the other $30 \%$ is derived from rock weathering and is therefore part of the slow carbon cycle and has no atmospheric origin (Ciais et al. 2008; Einsele et al. 2001).

In our analysis, we used the flux estimate of Lauerwald et al. (2015) for $\mathrm{CO}_{2}$ emission ${ }_{\text {lotic }}$, since this study simulates $\mathrm{CO}_{2}$ emissions from running waters at a much higher resolution than earlier approaches. To our knowledge, no global estimates for $\mathrm{GPP}_{\text {lotic }}$ and $\mathrm{CCP}_{\text {lotic }}$ exist. We set $\mathrm{GPP}_{\text {lotic }}$ and $\mathrm{CCP}_{\text {lotic }}$ to zero when testing the sensitivity of $\mathrm{DIC}_{\text {export }}$ to lake functioning, since the fluxes in streams and rivers were kept constant for all three functional lake classes and thus did not influence the result of the sensitivity analysis. Except for the estimates for $\mathrm{GPP}_{\text {lake }}$ and $\mathrm{MIN}_{\text {lake }}$ (Pace and Prairie 2005) as well as $\mathrm{MIN}_{\text {lotic }}$ (Caraco and Cole 1999), which were indi-

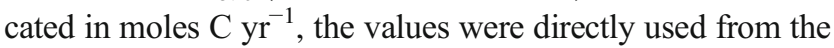
cited publications. The fluxes given in moles ${\mathrm{C} \mathrm{yr}^{-1}}^{-1}$ were converted into fluxes in $\mathrm{g} \mathrm{C} \mathrm{yr}^{-1}$ by multiplying the given values by the atomic mass of carbon. For flux estimates reported as a range in the original study, we used the mid-range for our calculations. The uncertainties presented here indicate the range of the estimates reported in the respective studies (Table 1). The uncertainties of the respective flux estimates used in Eqs. 1, 2, and 3 were summed, resulting in the reported uncertainties of $\mathrm{DIC}_{\text {export }}$. In our calculations, $\mathrm{GPP}_{\text {lake }}$ comprises $\mathrm{CO}_{2}$ uptake by phytoplankton from all available sources (Lewis Jr. 2011), and $\mathrm{MIN}_{\text {lake }}$ is a lumped value for the total pelagic and sediment mineralization of autochthonous and allochthonous organic carbon (Pace and Prairie 2005). For a more detailed description of the values used to calculate $\mathrm{DIC}_{\text {export }}$, consult the respective studies cited in Table 1.

\section{Sensitivity of terrestrial DIC export to uncertainties in global flux estimates}

The lateral DIC export from terrestrial ecosystem to inland waters is currently highly uncertain (Drake et al. 2017), complicating the calculation of global terrestrial carbon sinks/sources (Butman et al. 2016). The different global estimates used to calculate $\mathrm{DIC}_{\text {export }}$ (Table 1) each entail an uncertainty that sums to the uncertainty of our calculated $\mathrm{DIC}_{\text {export }}$ Uncertainties in $\mathrm{DIC}_{\text {export }}$ have previously been estimated as $\sim \pm 1.0 \mathrm{Pg} \mathrm{C} \mathrm{yr}^{-1}$ (Regnier et al. 2013), which is close to the uncertainty of our calculated $\mathrm{DIC}_{\text {export }}$ of $1.52_{-0.90}^{+1.09}$ (Eq. 1). Although DIC export $_{\text {lies most like- }}$ ly between 0.70 and $1.52 \mathrm{Pg} \mathrm{C} \mathrm{yr}^{-1}$, the full range of the calculated $\mathrm{DIC}_{\text {export }}$ when considering the upper and lower boundary value for active carbon transformers and intermediate active carbon transformers is 0.39 to $2.61 \mathrm{Pg} \mathrm{C} \mathrm{yr}^{-1}$ (Fig. 3).

To demonstrate the relevance of our functional lake classification concept in comparison to the uncertainties of the global flux estimates used in Eqs. 1, 2, and 3, we performed an analysis on the sensitivity of $\mathrm{DIC}_{\text {export }}$ to uncertainties in the global flux estimates used (Table 1). We varied each respective value used in Eqs. 1, 2, and 3 by $\pm 25 \%$ and compared our

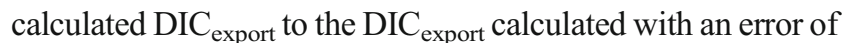
$\pm 25 \%$ ( DIC $_{\text {export error }}$ ). While the differences in lake function-

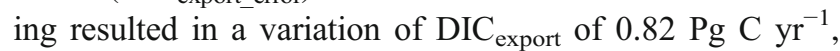
$\mathrm{DIC}_{\text {export error }}$ differed from $\mathrm{DIC}_{\text {export }}$ by $0.76,0.35$, and 0.51 $\mathrm{Pg} \mathrm{C} \mathrm{yr}{ }^{-1}$ for active carbon transformers, intermediate active carbon transformers, and passive open channels, respectively. Thus, when assuming an error of $\pm 25 \%$ for each respective 


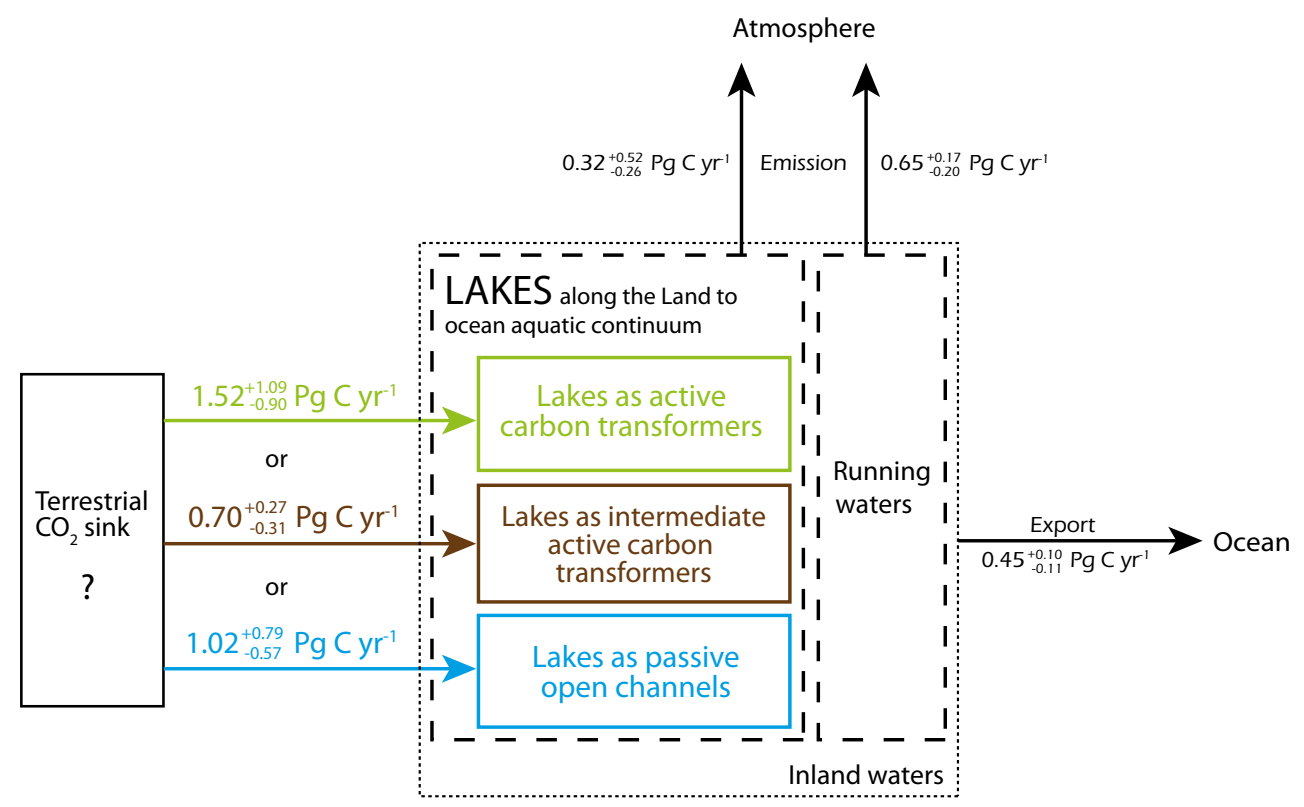

Fig. 3 Effect of considered functioning of global lakes on estimates of the lateral dissolved inorganic carbon (DIC) export from terrestrial ecosystems to inland waters in relation to $\mathrm{CO}_{2}$ transport from inland waters to the atmosphere and the ocean. Depending on the considered functioning of global lakes, the calculated lateral DIC export from

flux term in Eqs. 1, 2, and 3, the variability in $\mathrm{DIC}_{\text {export }}$ resulting from different assumptions on lake functioning was larger than the variability between $\mathrm{DIC}_{\text {export }}$ and DIC $_{\text {exporterror }}$ These results further highlight the importance of considering lake functioning when calculating $\mathrm{DIC}_{\text {export }}$.

When testing the sensitivity of DIC $_{\text {export }}$ to lake functioning, we set $\mathrm{GPP}_{\text {lotic }}$ and $\mathrm{CCP}_{\text {lotic }}$ to zero, since to our knowledge, no global estimates on $\mathrm{GPP}_{\text {lotic }}$ and $\mathrm{CCP}_{\text {lotic }}$ exist. To examine the effect of setting $\mathrm{GPP}_{\text {lotic }}$ (that is definitely $>0$ ) to zero when testing the sensitivity of $\mathrm{DIC}_{\text {export }}$ to lake functioning, we assumed $\mathrm{GPP}_{\text {lotic }}$ as $25 \%$ of $\mathrm{GPP}_{\text {lake }}$ and re-calculated

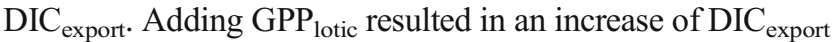
for active carbon transformers (Eq. 1) of $21 \%$. We did not test for the effect of non-zero $\mathrm{GPP}_{\text {lotic }}$ for the other lake types, since we had assumed GPP $_{\text {lake }}$ to approach zero for intermediate active and passive lakes, and $\mathrm{GPP}_{\text {lotic }}$ is usually considerably smaller than $\mathrm{GPP}_{\text {lake. }}$

\section{Spatial variations in lake functioning}

Our calculated $\mathrm{DIC}_{\text {export }}$ estimates were based on the assumption that all lakes on Earth are either active carbon transformers, intermediate active carbon transformers, or passive open channels. This assumption does not depict reality since in some regions on Earth, lakes will rarely function as passive open channels or active carbon transformers. Although it is beyond the scope of this study to allocate a lake function to each of the 117 million lakes on Earth, we made a rough terrestrial ecosystems to inland waters varies between $0.70_{-0.31}^{+0.27}$ and $1.52_{-0.90}^{+1.09} \mathrm{Pg} \mathrm{C} \mathrm{yr}^{-1}$. The DIC transformation and $\mathrm{CO}_{2}$ emission in running waters are kept constant for all cases. Numbers in black font from Cole et al. (2007), Raymond et al. (2013), and Lauerwald et al. (2015)

estimate of how many lakes potentially can function as active carbon transformers or as passive open channels. Based on Lewis Jr. (2011), we assumed that all lakes located between $39^{\circ} \mathrm{N}$ and $39^{\circ} \mathrm{S}$ have the potential to function as active carbon transformers. We chose this latitude as a borderline for potentially active lakes, since the modeled median lake gross primary production of global lakes increases sharply between $42.5^{\circ}$ and $37.5^{\circ}$ latitude from $\sim 400$ to $\sim 800 \mathrm{~g} \mathrm{C} \mathrm{m}^{-2} \mathrm{yr}^{-1}$ (Lewis Jr. 2011). Accordingly, we assumed that all lakes between $54^{\circ} \mathrm{N}$ and $84^{\circ} \mathrm{N}$ may function as passive open channels as these lakes are located in the boreal and subarctic zone, are usually small and shallow, and often function as passive open channels (Weyhenmeyer et al. 2015). Even if not taken into consideration in this estimate, it must be noted that a substantial number of humic-rich boreal lakes most probably function as intermediate active carbon transformers. We did not assign lakes located between $39^{\circ}$ and $54^{\circ}$ latitude to any of our three categories, since the functioning of lakes within these latitudinal bands might vary strongly depending on nutrient conditions, hydrology, catchment characteristics, lake morphology, and regional climate.

Using the abundance and total area of lakes for $3^{\circ}$ latitudinal bands from the Global Water Body database (GLOWABO) (Verpoorter et al. 2014), we found that about $25 \%$ of lakes on Earth, corresponding to $35 \%$ of the global lake area, potentially function as passive open channels, while $60 \%$ of lakes, corresponding to $45 \%$ of the global lake area, might act predominantly as active carbon transformers. Since the functioning of different lakes within an ecoregion varies 
widely (McDonald et al. 2013; Weyhenmeyer et al. 2015), this estimate is a first-order approximation of the global distribution of lake functions according to our conceptual model and can serve as an exemplifying application of our classification concept. This classification according to latitudinal distribution only accounts for the control of climate on lake functioning. Additional factors including hydrologic regime, land-use, and regional geography can exert strong influences on lake functioning and should be considered in future, more accurate estimates of the functioning of lakes in the global carbon cycle.

\section{Refining terrestrial DIC export estimates}

We focused our analysis on the role of lakes as modulators of DIC transport and transformation. It has to be noted that the functioning of streams, rivers, floodplains, and wetlands is also of high importance for DIC transport and transformation along the LOAC (Aufdenkampe et al. 2011; Raymond et al. 2013). At the current stage, the use of our conceptual model for calculating the global lateral DIC export from terrestrial ecosystems to inland waters has limitations, which future studies should address, when more whole-lake carbon budgets and estimates of global carbon fluxes are available. At present, our lake classification concept (Figs. 1 and 2) applies only to open lake systems along the LOAC. While this is the prevalent lake type globally, closed basins can play an important role in arid and semi-arid regions (Einsele et al. 2001; Li et al. 2017). The function of these lakes in the global carbon cycle is presently unknown; however, a recent study estimated that in global closed drainage basins, about $0.15 \mathrm{Pg} \mathrm{C} \mathrm{yr}^{-1}$ of the incoming DIC is stored ( $\mathrm{Li}$ et al. 2017). Our estimates are also limited by the lack of data for global $\mathrm{GPP}_{\text {lotic }}$ and $\mathrm{CCP}_{\text {lotic }}$. We assumed these fluxes to be zero in Eqs. 1, 2, and 3, but performed a sensitivity analysis to demonstrate the effect of $\mathrm{GPP}_{\text {lotic }}$ on our $\mathrm{DIC}_{\text {export }}$ estimate according to Eq. 1. As GPP lotic and $\mathrm{CCP}_{\text {lotic }}$ are larger than zero, including estimates for $\mathrm{GPP}_{\text {lotic }}$ and $\mathrm{CCP}_{\text {lotic }}$ would increase the calculated $\mathrm{DIC}_{\text {export }}$ rates. Further, the global estimate of $\mathrm{CCP}_{\text {lake }}$ (Table 1) used in Eq. 1 is relatively low, considering that some lakes, e.g., Attersee and Lake Constance, precipitate $4-17 \%$ of the incoming carbonate (Einsele et al. 2001). Thus, we suggest that our estimates for $\mathrm{DIC}_{\text {export }}$ are conservative, particularly since we used the most recent global estimate for $\mathrm{CO}_{2}$ emission $_{\text {lotic }}$ from Lauerwald et al. (2015) that is substantially lower than earlier estimates of $\mathrm{CO}_{2}$ emission emic $_{\text {lot }}$ (Table 1).

A significant amount of uncertainty in our calculated $\mathrm{DIC}_{\text {export }}$ arises from the variability in lake primary production that complicates quantification of global lake $\mathrm{CO}_{2}$ consumption. Lake primary production along a global latitudinal gradient can vary by a factor of 1000 (Jonsson et al. 2003; Melack and Kilham 1974) and significantly differs for individual lakes on decadal scale in relation to climate variation (Pettersson et al. 2003). Depending on the estimates for global lake abundance used, Lewis Jr. (2011) reports a variation of global lake GPP between 1.05 and $1.51 \mathrm{Pg} \mathrm{C} \mathrm{yr}^{-1}$. This uncertainty of $0.46 \mathrm{Pg} \mathrm{C} \mathrm{yr}{ }^{-1}$ accounts for a variation in our calculated $\mathrm{DIC}_{\text {export }}$ for active carbon transformers (1.52 $\mathrm{Pg} \mathrm{C} \mathrm{yr}^{-1}$ acc. to Eq. 1) of about $30 \%$. Neglecting GPP lake in the global DIC budget that considers lakes as active carbon transformers (Eq. 1) would result in a reduction of the calculated DIC $_{\text {export }}$ by about $85 \%$. In our calculations, a large share of $\mathrm{GPP}_{\text {lake }}$ is from GPP in warm, nutrient-rich tropical lakes (Lewis Jr. 2011), which we classified as active carbon transformers. We assumed that all photosynthetically fixed $\mathrm{CO}_{2}$ in lakes is of terrestrial origin. This assumption is supported by the fact that a large majority of inland waters is supersaturated with $\mathrm{CO}_{2}$ and $\mathrm{CO}_{2}$ uptake from the atmosphere is minor in global lakes. However, the relative contribution of terrestrial vs. atmospheric-derived $\mathrm{CO}_{2}$ to photosynthetic $\mathrm{CO}_{2}$ fixation in inland waters is presently unknown (Drake et al. 2017). Assuming that a share of the photosynthetically fixed $\mathrm{CO}_{2}$ is taken up by lakes directly from the atmosphere would lower our estimates of $\mathrm{DIC}_{\text {export }}$ slightly. In lakes with high hydrologic DIC inputs, primary production can be influenced by terrestrially derived DIC, and $\mathrm{CO}_{2}$ emissions in net autotrophic lakes can mainly arise from hydrologic DIC inputs (Stets et al. 2009). Consequently, $\mathrm{CO}_{2}$ consumption by primary production in lakes along the LOAC needs to be considered when calculating terrestrial DIC export rates.

The single published estimates for the same global inland water DIC flux differ significantly (Table 1). The accuracy of the global estimates for inland water DIC fluxes partly depends on the resolution at which spatial variabilities are accounted for (Lauerwald et al. 2015; McDonald et al. 2013). The spatial resolution currently used to calculate carbon fluxes along the LOAC of maximum $0.5^{\circ}$ is too coarse to account for the diversity and regional distribution of soil types, wetlands, streams, rivers, and lakes (Lauerwald et al. 2015; Regnier et al. 2013). However, attempts to resolve, for example, $\mathrm{CO}_{2}$ emissions from the global river network at a higher resolution have progressed constantly during the past 10 years (Lauerwald et al. 2015). With ongoing refinements of global estimates of inland water DIC fluxes, our conceptual model, accounting for the predominant lake functions, can be a valuable tool for more robust estimates of the global DIC export from terrestrial ecosystems to inland waters.

Overall, we show here that the consideration of lake functioning is necessary to estimate the magnitude of the global DIC export from terrestrial ecosystems to inland waters. Similar to our estimations for DIC, we expect that our lake classification concept (Fig. 2) can also be applied to other carbon forms (e.g., DOC) as its transport and transformation processes vary strongly among lakes depending on lake characteristics. Since lake functioning differs widely across the 
globe (Lewis Jr. 2011; Tranvik et al. 2009), accurate estimates of the lateral DIC export will require the prediction of lake functioning for each of the 117 million lakes on Earth (McDonald et al. 2013; Verpoorter et al. 2014). With constant changes in anthropogenic carbon outputs altering the global carbon cycle (Regnier et al. 2013), and disturbances of natural conditions causing eutrophication or a global temperature rise, lake functioning is likely to change (Gudasz et al. 2010; Lewis Jr. 2011; Fig. 2). The continuously high activity in dam construction on global scale (Zarfl et al. 2015) will probably shift numerous riverine systems towards a state at which they predominantly act as active carbon transformers. Global climate change will likely increase the activity of already existing lakes and reservoirs in carbon transformation, especially in the temperate and boreal region (Flanagan et al. 2003; Gudasz et al. 2010; Tranvik et al. 2009). Thus, our functional lake classification concept becomes particularly important for the calculation of the future lateral DIC export from soils to inland waters and future estimations of terrestrial $\mathrm{CO}_{2}$ sinks and sources.

Author information Correspondence and requests for materials should be addressed to Fabian.Engel@ebc.uu.se

Funding information Financial support was received from the Swedish Research Council (Grant No. 2016-04153), the European Union's Horizon 2020 research and innovation program under the Marie Sklodowska-Curie grant agreement No 643052 (C-CASCADES project), and from the Knut and Alice Wallenberg Foundation (KAW project). This work profited from the Global Lake Ecological Observatory Network (GLEON). The Estonian partners were supported by institutional research funding IUT 21-02 of the Estonian Ministry of Education and Research, and American partners were supported, in part, through NSF EF1137327.

\section{Compliance with ethical standards}

Conflict of interest The authors declare that they have no conflict of interest.

Open Access This article is distributed under the terms of the Creative Commons Attribution 4.0 International License (http:// creativecommons.org/licenses/by/4.0/), which permits unrestricted use, distribution, and reproduction in any medium, provided you give appropriate credit to the original author(s) and the source, provide a link to the Creative Commons license, and indicate if changes were made.

\section{References}

Almeida RM, Nóbrega GN, Junger PC, Figueiredo AV, Andrade AS, de Moura CGB, Tonetta D, Oliveira ES, Araújo F, Rust F, PiñeiroGuerra JM, Mendonça JR, Medeiros LR, Pinheiro L, Miranda M, Costa MRA, Melo ML, Nobre RLG, Benevides T, Roland F, de Klein J, Barros NO, Mendonça R, Becker V, Huszar VLM, Kosten S (2016) High primary production contrasts with intense carbon emission in a eutrophic tropical reservoir. Front Microbiol 7. https://doi.org/10.3389/fmicb.2016.00717
Aufdenkampe AK, Mayorga E, Raymond PA, Melack JM, Doney SC, Alin SR, Aalto RE, Yoo K (2011) Riverine coupling of biogeochemical cycles between land, oceans, and atmosphere. Front Ecol Environ 9:53-60. https://doi.org/10.1890/100014

Battin TJ, Luyssaert S, Kaplan LA, Aufdenkampe AK, Richter A, Tranvik LJ (2009) The boundless carbon cycle. Nat Geosci 2:598600. https://doi.org/10.1038/ngeo618

Bauer JE, Cai W-J, Raymond PA, Bianchi TS, Hopkinson CS, Regnier PA (2013) The changing carbon cycle of the coastal ocean. Nature 504:61-70

Biddanda BA (2017) Global significance of the changing freshwater carbon cycle. Eos:98. https://doi.org/10.1029/2017EO069751

Butman D, Stackpoole S, Stets E, McDonald CP, Clow DW, Striegl RG (2016) Aquatic carbon cycling in the conterminous United States and implications for terrestrial carbon accounting. Proc Natl Acad Sci U S A 113:58-63. https://doi.org/10.1073/pnas.1512651112

Caraco N, Cole J (1999) Regional-scale export of C, N, P, and sediment: what river data tell us about key controlling variables. In: Biogeochemistry in complex landscapes Wiley, pp 233-244

Catalán N, Marcé R, Kothawala DN, Tranvik LJ (2016) Organic carbon decomposition rates controlled by water retention time across inland waters. Nat Geosci 9:501-504

Ciais P, Borges AV, Abril G, Meybeck M, Folberth G, Hauglustaine D, Janssens IA (2008) The impact of lateral carbon fluxes on the European carbon balance. Biogeosciences 5:1259-1271

Cole JJ, Prairie YT, Caraco NF, McDowell WH, Tranvik LJ, Striegl RG, Duarte CM, Kortelainen P, Downing JA, Middelburg JJ, Melack J (2007) Plumbing the global carbon cycle: integrating inland waters into the terrestrial carbon budget. Ecosystems 10:171-184. https:// doi.org/10.1007/s10021-006-9013-8

Drake TW, Raymond PA, Spencer RGM (2017) Terrestrial carbon inputs to inland waters: a current synthesis of estimates and uncertainty. Limnol Oceanogr Lett. https://doi.org/10.1002/lol2.10055

Einsele G, Yan J, Hinderer M (2001) Atmospheric carbon burial in modern lake basins and its significance for the global carbon budget. Glob Planet Chang 30:167-195

Falkowski P, Scholes RJ, Boyle E, Canadell J, Canfield D, Elser J, Gruber N, Hibbard K, Högberg P, Linder S, Mackenzie FT, Moore B 3rd, Pedersen T, Rosenthal Y, Seitzinger S, Smetacek V, Steffen W (2000) The global carbon cycle: a test of our knowledge of earth as a system. Science 290:291-296

Fisher JB, Huntzinger DN, Schwalm CR, Sitch S (2014) Modeling the terrestrial biosphere. Annu Rev Environ Resour 39:91-123

Flanagan KM, McCauley E, Wrona F, Prowse T (2003) Climate change: the potential for latitudinal effects on algal biomass in aquatic ecosystems. Can J Fish Aquat Sci 60:635-639

Gudasz C, Bastviken D, Steger K, Premke K, Sobek S, Tranvik LJ (2010) Temperature-controlled organic carbon mineralization in lake sediments. Nature 466:478-481

Houghton RA (2003) Why are estimates of the terrestrial carbon balance so different? Glob Chang Biol 9:500-509

IPCC (2013) Climate change 2013: the physical science basis. Contribution of Working Group I to the Fifth Assessment Report of the Intergovernmental Panel on Climate Change. In: Stocker, T.F., D. Qin, G.-K. Plattner, M. Tignor, S.K. Allen, J. Boschung, A. Nauels, Y. Xia, V. Bex and P.M. Midgley (eds.), Cambridge, United Kingdom and New York, NY, USA. https://doi.org/10. 1017/CBO9781107415324

Jonsson A, Karlsson J, Jansson M (2003) Sources of carbon dioxide supersaturation in clearwater and humic lakes in northern Sweden. Ecosystems 6:224-235

Jonsson A, Meili M, Bergstrom AK, Jansson M (2001) Whole-lake mineralization of allochthonous and autochthonous organic carbon in a large humic lake (Ortrasket, N. Sweden). Limnol Oceanogr 46: $1691-1700$ 
Langerwisch F, Walz A, Rammig A, Tietjen B, Thonicke K, Cramer W (2016) Climate change increases riverine carbon outgassing, while export to the ocean remains uncertain. Earth Syst Dyn 7:559-582

Lauerwald R, Laruelle GG, Hartmann J, Ciais P, Regnier PA (2015) Spatial patterns in $\mathrm{CO} 2$ evasion from the global river network. Glob Biogeochem Cycles 29:534-554

Lewis Jr WM (2011) Global primary production of lakes: 19th Baldi Memorial Lecture Inland Waters 1:1-28

Li Y, Zhang C, Wang N, Han Q, Zhang X, Liu Y, Xu L, Ye W (2017) Substantial inorganic carbon sink in closed drainage basins globally. Nat Geosci 10:501-506

McDonald CP, Stets EG, Striegl RG, Butman D (2013) Inorganic carbon loading as a primary driver of dissolved carbon dioxide concentrations in the lakes and reservoirs of the contiguous United States. Glob Biogeochem Cycles 27:285-295

Melack JM, Kilham P (1974) Photosynthetic rates of phytoplankton in East African alkaline, saline lakes. Limnol Oceanogr 19:743-755

Meybeck M (1993) Riverine transport of atmospheric carbon-sources, global typology and budget. Water Air Soil Pollut 70:443-463. https://doi.org/10.1007/bf01105015

Nakayama T (2017) Development of an advanced eco-hydrologic and biogeochemical coupling model aimed at clarifying the missing role of inland water in the global biogeochemical cycle. J Geophys Res Biogeosci 122:966-988

Oquist MG et al (2014) The full annual carbon balance of boreal forests is highly sensitive to precipitation. Environ Sci Technol Lett 1:315319. https://doi.org/10.1021/ez500169j

Pace ML, Prairie YT (2005) Respiration in lakes. In: Respiration in aquatic ecosystems, pp 103-121

Pettersson K, Grust K, Weyhenmeyer G, Blenckner T (2003) Seasonality of chlorophyll and nutrients in Lake Erken - effects of weather conditions. Hydrobiologia 506:75-81. https://doi.org/10.1023/b:hydr. 0000008582.61851 .76

Raymond PA, Hartmann J, Lauerwald R, Sobek S, McDonald C, Hoover M, Butman D, Striegl R, Mayorga E, Humborg C, Kortelainen P, Dürr H, Meybeck M, Ciais P, Guth P (2013) Global carbon dioxide emissions from inland waters. Nature 503:355-359. https://doi.org/ 10.1038 /nature 12760

Regnier P, Friedlingstein P, Ciais P, Mackenzie FT, Gruber N, Janssens IA, Laruelle GG, Lauerwald R, Luyssaert S, Andersson AJ, Arndt S, Arnosti C, Borges AV, Dale AW, Gallego-Sala A, Goddéris Y, Goossens N, Hartmann J, Heinze C, Ilyina T, Joos F, LaRowe DE, Leifeld J, Meysman FJR, Munhoven G, Raymond PA, Spahni R, Suntharalingam P, Thullner M (2013) Anthropogenic perturbation of the carbon fluxes from land to ocean. Nat Geosci 6:597-607. https://doi.org/10.1038/ngeo1830

Schimel DS (1995) Terrestrial ecosystems and the carbon cycle. Glob Chang Biol 1:77-91

Stets EG, Striegl RG, Aiken GR, Rosenberry DO, Winter TC (2009) Hydrologic support of carbon dioxide flux revealed by whole-lake carbon budgets Journal of Geophysical Research-Biogeosciences 114. https://doi.org/10.1029/2008jg000783

Tranvik LJ, Downing JA, Cotner JB, Loiselle SA, Striegl RG, Ballatore TJ, Dillon P, Finlay K, Fortino K, Knoll LB, Kortelainen PL, Kutser T, Larsen S, Laurion I, Leech DM, McCallister SL, McKnight DM, Melack JM, Overholt E, Porter JA, Prairie Y, Renwick WH, Roland F, Sherman BS, Schindler DW, Sobek S, Tremblay A, Vanni MJ, Verschoor AM, von Wachenfeldt E, Weyhenmeyer GA (2009) Lakes and reservoirs as regulators of carbon cycling and climate. Limnol Oceanogr 54:2298-2314. https://doi.org/10.4319/lo.2009. 54.6 part 2.2298

Verpoorter C, Kutser T, Seekell DA, Tranvik LJ (2014) A global inventory of lakes based on high-resolution satellite imagery. Geophys Res Lett 41:6396-6402

Weyhenmeyer GA, Kosten S, Wallin MB, Tranvik LJ, Jeppesen E, Roland F (2015) Significant fraction of CO2 emissions from boreal lakes derived from hydrologic inorganic carbon inputs. Nat Geosci 8:933-938. https://doi.org/10.1038/ngeo2582

Zarfl C, Lumsdon AE, Berlekamp J, Tydecks L, Tockner K (2015) A global boom in hydropower dam construction. Aquat Sci 77:161170. https://doi.org/10.1007/s00027-014-0377-0 